Article

\title{
Estimation of Tunisian Greenhouse Gas Emissions from Different Livestock Species
}

\author{
Hajer Ammar ${ }^{1, *, \dagger}$, Sourour Abidi ${ }^{2,+}\left(\mathbb{D}\right.$, Mediha Ayed $^{3}$, Nizar Moujahed ${ }^{4}$, \\ Mario E. deHaro Martí ${ }^{5}$, Mireille Chahine ${ }^{6}$, Rachid Bouraoui ${ }^{7}$, Secundino López ${ }^{8, *(\mathbb{D} \text {, }}$ \\ Hatem Cheikh M'hamed $^{9}$ and Haikel Hechlef ${ }^{10}$ \\ 1 Higher Agriculture School of Mograne, 1121 Mograne, University of Carthage Tunisia, \\ Zaghouan 1100, Tunisia \\ 2 Laboratory of Animal and Forage Production, National Institute of Agronomic Research of Tunis, \\ Street Hédi Karray, El Manzah 1004, University of Carthage, Carthage 1054, Tunisia; sourour.abidi@yahoo.fr \\ 3 Higher Agriculture Institute of Chott Meriam (ISCM), Department of Animal Resources, Agri-food and \\ Rural Development, University of Sousse, Sousse 4047, Tunisia; mediha.ayed@yahoo.fr \\ 4 Agronomic National Institute of Tunisia (INAT), Unity of Ecosystem Research and Aquatic Ressources, \\ 43 Street Charles Nicolle, Tunis-Mahrajène 1082, University of Carthage, Carthage 1054, Tunisia; \\ nizar.moujahed@yahoo.fr \\ 5 Gooding County Extension, University of Idaho, 203 Lucy Lane, Gooding, ID 83330, USA; \\ mdeharo@uidaho.edu \\ 6 Department of Animal and Veterinary Sciences, University of Idaho, PO Box 1827, Twin Falls, ID 83303, USA; \\ mchahine@uidaho.edu \\ 7 Higher Agriculture School of Mateur, Mateur, Bizerte 7030, University of Carthage, Carthage 1054, Tunisia; \\ bouraoui.rachid@yahoo.fr \\ 8 Instituto de Ganadería de Montaña (IGM), CSIC-Universidad de León, Departamento de Producción \\ Animal, Universidad de León, E-24007 León, Spain \\ 9 Agronomy Laboratory, Street Hédi Karray, National Institute of Agronomic Research of Tunis, \\ El Manzah 1004, University of Carthage, Carthage 1054, Tunisia; hatemcheikh@yahoo.fr \\ 10 Ministry of Agriculture, Maritime Fisheries and Hydraulic Ressources, 30 Street Alain Savarey, \\ Tunis 1002, Tunisia; haikelhechlef@gmail.com \\ * Correspondence: hjr.mmr@gmail.com (H.A.); s.lopez@unileon.es (S.L.) \\ + Authors contributing equally to the fulfillment of this work.
}

Received: 19 October 2020; Accepted: 5 November 2020; Published: 20 November 2020

check for updates

\begin{abstract}
This study aimed to determine the emissions of methane $\left(\mathrm{CH}_{4}\right)$ and nitrous oxide $\left(\mathrm{N}_{2} \mathrm{O}\right)$ from seven Tunisian livestock species and their evolution over eleven consecutive years (2008-2018). The species of animals used were cattle (dairy and others), sheep, goats, camelids, horses, donkeys and mules, and poultry. The estimations of $\mathrm{CH}_{4}$ and $\mathrm{N}_{2} \mathrm{O}$ emissions were based on the Intergovernmental Panel on Climate Change (IPCC) guidelines for national inventories, using Tier 1 and Tier 2 approaches, with its default emission factors (EFs). The Tier 2 approach was applied only for the calculation of EF to estimate $\mathrm{CH}_{4}$ emissions related to livestock manure management. $\mathrm{CH}_{4}$ emission represented more than $92 \%$ of the total greenhouse gas (GHG) from livestock emissions. Moreover, $53 \%$ of the total $\mathrm{CH}_{4}$ emissions from livestock were derived from cattle, followed by sheep, goats, other mammals (camelids, horses, mules, and donkeys), and poultry. During the period covered by the study (2008-2018), a slight and continuous decrease of both livestock population and total GHG emissions was observed, mainly in terms of $\mathrm{CH}_{4}$. In mammals, $\mathrm{CH}_{4}$ emissions were greater than $\mathrm{N}_{2} \mathrm{O}$ emissions, whereas in poultry, $\mathrm{N}_{2} \mathrm{O}$ emissions were up to 2.6 times greater than $\mathrm{CH}_{4}$ emissions. The aggressive drive of the government to increase cattle and sheep production might affect $\mathrm{CH}_{4}$ emissions in the future. Therefore, periodic estimations of GHG emissions from livestock are required to follow the time trends for more rational decision-making regarding livestock and GHG emissions policies.
\end{abstract}


Keywords: livestock; enteric fermentation; manure management; methane; nitrous oxide; emission factor

\section{Introduction}

In many African countries, agriculture remains the largest economic sector. It supplies up to 50\% of household food requirements and up to $50 \%$ of household incomes [1,2]. In Tunisia, about $20 \%$ of the population is employed in agriculture, which accounts for about $10 \%$ of the country's gross domestic product, and about 10 to $12 \%$ of total exports [3,4]. As such, agriculture is essential for the overall economy. On the other hand, the agricultural sector (crop and livestock production) contributes

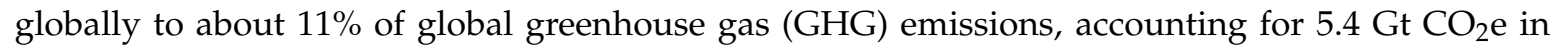
2012 [5]. About $60 \%$ of the total agricultural emissions are due to livestock emission sources. Enteric fermentation is considered the biggest contributor (about 63\%) of livestock emissions, followed by manure management $(12 \%)$ and application of dung and urine on pasture (25\%) [5]. Other emissions related to livestock include energy use in livestock supply chains, GHG emissions in feed production, and emissions from land use changes [6]. While total GHG emissions from livestock production in developed countries as a whole have declined in recent decades, emissions in most developing countries have increased significantly [5] and are expected to increase in the coming decades. As a response to GHG emissions and their impact on climate change, Tunisia is expected to see an increase in droughts. This will particularly affect rain fed cereal farmland, which is expected to decrease from a current average land area of 1.5 million hectares to about 1 million hectares in 2030, i.e., a reduction of approximately $30 \%$ [7]. Likewise, in the event of successive extreme droughts, the land area used for cereal crops and arboriculture (mainly in regions in the centre and the south) will decrease by 200,000 and 800,000 hectares, respectively. Lastly, the livestock population would decrease by about $80 \%$ in the centre and the south, and $20 \%$ in the north, owing to the loss of grasslands and grazing areas. Tunisia is aware of these challenges and has carried out five complete GHG inventory operations in 1994, 2000, 2010, 2011, and 2012.

According to the last inventory, Tunisia's GHG net emissions reached $32,600 \mathrm{Gg}$ of $\mathrm{CO}_{2}$ equivalent $\left(\mathrm{Gg} \mathrm{CO}_{2} \mathrm{e}\right)$ in 2012 [8,9]. $\mathrm{CO}_{2}$ was the major gas emitted $(69 \%)$ followed by $\mathrm{CH}_{4}(21.9 \%)$ and $\mathrm{N}_{2} \mathrm{O}(7.9 \%)$. The energy sector was the largest contributor to net GHG emissions, with $27,023 \mathrm{Gg} \mathrm{CO}_{2} \mathrm{e}$, representing $83 \%$ of the 2012 national net emissions. More than $90 \%$ of the emissions attributable to energy are due to combustion (92\%) [8,9]. Given the relatively major importance of the agriculture sector in Tunisia [3], total GHG emissions from the agriculture, forestry, and other land use (AFOLU) sector in Tunisia in 2012 were 6568,2636 , and $1945 \mathrm{Gg} \mathrm{CO}_{2} \mathrm{e}$ as $\mathrm{CO}_{2}, \mathrm{CH}_{4}$, and $\mathrm{N}_{2} \mathrm{O}$, respectively. However, some cultivated land (mainly olive groves and arboriculture) and forests contribute to the absorption of $14,028 \mathrm{Gg} \mathrm{CO}_{2}$ from the atmosphere. Therefore, although gross GHG emissions from AFOLU account for $24 \%(11,149$ $\mathrm{GgCO} \mathrm{CO}_{2} \mathrm{e}$ of the total emissions in Tunisia, overall, this sector is considered a net GHG absorber, with a final balance of minus $2900 \mathrm{Gg} \mathrm{CO}_{2} \mathrm{e}$ (negative emission indicating a net absorption of $\mathrm{CO}_{2}$ ) [8,9]. However, carbon sequestration is only in the form of $\mathrm{CO}_{2}$, so that regarding other GHGs, AFOLU contributes to $37 \%$ and $76 \%$ of the $\mathrm{CH}_{4}$ and $\mathrm{N}_{2} \mathrm{O}$ total emissions in Tunisia, respectively. As for the structure of GHG emissions within the AFOLU sector, livestock-related emissions account for $26 \%$ of agricultural GHG emissions, whereas the contributions from other agricultural activities were estimated as $32 \%$ from wood use (mainly wood-energy) and $26 \%$ from land use (mainly carbon losses in grasslands) [8,9]. Measurement of livestock GHG emissions and its evolution is relevant for the estimation of total GHG emissions [6,10]. Better characterization of livestock GHG emissions can assist scientists and policy makers in targeting solutions and design efforts to mitigate GHG emissions [10]. The national inventory of GHGs from Tunisia reported to the United Nations Framework Convention on Climate Change (UNFCCC) [8,9] does not specify which GHG emissions correspond to $\mathrm{CH}_{4}$ or $\mathrm{N}_{2} \mathrm{O}$, and how these emissions can be assigned to each animal species farmed in the country. This information 
is required to identify gaps of knowledge to achieve more accurate estimations and issues that can be targeted to implement mitigation or adaptation measures. Generally, the estimation of GHG is based on 2006 Intergovernmental Panel on Climate Change (IPCC) guidelines [11] using Tier 1 or Tier 2 approaches. Wilkes et al. [6] reported that, among 140 developing countries, 119 use a Tier 1 approach, and only 21 countries use a Tier 2 approach. Tier 1 methodologies use fixed values for GHG emissions per head of livestock, so changes in total emissions are responsive only to changes in animal numbers and populations. However, Tier 2 methodologies require enhanced classification of different types of livestock and data on livestock weight, weight gain, feed digestibility, level of production, and other factors. Tier 2 methodologies are supposed to better capture the management of GHG emissions and to provide higher precision. In Tunisia, a developing country, to the best of our knowledge, there is no study carried out on the quantification of GHGs issued from the different livestock species. Therefore, the objective of our study was to calculate the GHG emissions, mainly $\mathrm{CH}_{4}$ and $\mathrm{N}_{2} \mathrm{O}$, from the Tunisian livestock sector, estimating the emissions from each farm animal species (ruminants, camelids, equines, and poultry) using the Tier 1 and Tier 2 (when feasible) methods of the 2006 IPCC guidelines. The study used data from eleven consecutive years (2008-2018) in order to examine the trend in GHG emissions from livestock over this period. This would be the first comprehensive and differentiated assessment of emissions in the country, and may be a fundamental and initial step firstly to evaluate the reliability of the estimations and to identify the gaps in the assumptions made and the limitations in the calculations, aiming at refining the approaches used to improve the accuracy of such estimations. Secondly, once more reliable estimations are available, in the medium term, it could be possible to make decisions on the proposal of mitigation and adaptation strategies that could be implemented to reduce the environmental impact of GHG emissions.

\section{Material and Methods}

It is pertinent to mention that GHG emissions were estimated from the total domestic livestock species annually present in the whole country, irrespectively of region localization, climatic conditions, and production system.

\subsection{Country Geographic Situation and Climatic Data}

Tunisia is a North African country covering an area of $164,000 \mathrm{~km}^{2}$ with $1300 \mathrm{~km}$ of coastline on the Mediterranean Sea and about 11 million inhabitants in 2014. The country is located between longitudes $7^{\circ}$ and $12^{\circ}$ east and latitudes $32^{\circ}$ and $38^{\circ}$ north. The relatively high latitude of Tunisia within Africa and its geographical stretch from South to North conferred to the country the following climatic zones: humid to sub-humid in the extreme north; sub-humid to semi-arid in the northwest and the Cap Bon region; and semi-arid to arid in central Tunisia and desert in the south. Consequently, temperatures vary widely between regions. In the northern coastal region, average temperatures range from a minimum of $10^{\circ} \mathrm{C}$ in the winter months (i.e., December-February) to a maximum of $27^{\circ} \mathrm{C}$ in the summer months (i.e., June-August), while in the central-western and southern regions, temperatures range from $11^{\circ} \mathrm{C}$ (in winter) to $32^{\circ} \mathrm{C}$ (in summer). Thus, Tunisia is considered one of the most exposed countries to climate change in the Mediterranean area [12]. It faces risks associated with temperature increases, reduced precipitation, rising sea levels, and more frequent extreme weather phenomena (floods and droughts). During the last 30 years, the temperature has increased by an average of $0.4{ }^{\circ} \mathrm{C}$ per decade and, during the same period, the average annual precipitation has decreased by about $3 \%$.

\subsection{Estimation of Animal Population and GHG Emissions}

For the livestock production sector, activity data present the head numbers of the different species/category of domestic livestock in Tunisia based on data provided by the Ministry of agriculture [4]. We identified the following species: cattle (dairy and non-dairy cattle), sheep, goats, camelids, equines (horses, mules and donkeys), and poultry. 
Estimation of the average annual population $\left(\mathrm{AAP}_{T}\right)$ corresponding to each animal species/category $T$ was determined by the following equation:

$$
\mathrm{AAP}_{T}=\frac{\mathrm{NDA}_{T}}{365} \times \mathrm{NAPA}_{T}
$$

where $\mathrm{NDA}_{T}$ is the number of days alive and $\mathrm{NAPA}_{T}$ is the number of animals produced annually of each species/category $T$.

\subsubsection{Methane $\left(\mathrm{CH}_{4}\right)$ Emissions}

Estimation of $\mathrm{CH}_{4}$ emissions derived from enteric fermentation was based on the multiplication of numbers of livestock heads by the corresponding emission factors (EFs) provided by IPCC 2006 [11]. In our present study, estimation was carried out only at the Tier 1 level as there are a lack of advanced data to implement a specific Tier 2 methodology. The Tier 1 method can be applied for the livestock, except for cattle, where data issued from East Europe (dairy cows) and Latin America (other cows) were used. The general equation for estimating livestock methane emissions is as follows:

$$
\mathrm{CH}_{4}=\sum_{T} \frac{\left(E F_{(T)} \times N_{(T)}\right)}{10^{6}}
$$

where $\mathrm{CH}_{4}$ is the emission of methane $\left(\mathrm{Gg} \mathrm{CH}_{4} \cdot\right.$ year $\left.^{-1}\right)$ for a defined population, $E F_{(T)}$ is the emission factor for animal species/category $T\left(\mathrm{~kg} \mathrm{CH}_{4} \cdot\right.$ head $\left.^{-1} \cdot \mathrm{year}^{-1}\right)$, and $N_{(T)}$ is the number of heads of livestock species/category $T\left(\mathrm{AAP}_{T}\right.$ from Equation (1)). Equation (2) was applied to calculate the annual $\mathrm{CH}_{4}$ emission derived either from enteric fermentation or from manure management. Emission factors used to calculate $\mathrm{CH}_{4}$ from enteric fermentation $\left(E F_{\text {enteric }}\right)$ for sheep, goats, equines (horses, donkeys, and mules), and camelids correspond to those proposed by IPCC [11] for developing countries (Table 1).

Table 1. Emission factors corresponding to methane $\left(\mathrm{kg} \mathrm{CH}_{4} \cdot \mathrm{head}^{-1}\right.$.year $\left.{ }^{-1}\right)$ issued from enteric fermentation $\left(E F_{\text {enteric }}\right)$ and manure management $\left(E F_{\text {manure }}\right)$, volatile solids excreted daily $(V S, \mathrm{~kg}$ dry matter.animal ${ }^{-1}$. day $\left.{ }^{-1}\right)$, the maximal capacity of methane production from manure produced $\left(B_{O}, \mathrm{~m}^{3}\right.$

\begin{tabular}{|c|c|c|c|c|c|c|c|c|c|c|}
\hline \multirow{2}{*}{$\begin{array}{l}\text { Animal } \\
\text { Species }\end{array}$} & \multicolumn{2}{|c|}{ Cattle } & \multirow{2}{*}{ Sheep } & \multirow{2}{*}{ Goats } & \multicolumn{2}{|c|}{ Equines } & \multirow{2}{*}{$\begin{array}{l}\text { Camelids } \\
\text { /Mules }\end{array}$} & \multicolumn{3}{|c|}{ Poultry } \\
\hline & Dairy & Others & & & Horses & Donkeys, & & Laying & Broiler & Turkey \\
\hline EF $F_{\text {enteric }}$ & 89 & 58 & 5 & 5 & 18 & 10 & 46 & 0 & 0 & 0 \\
\hline$E F_{\text {manure }}$ & 9 & 4 & 0.22 & 0.24 & 0.97 & 2.1 & 4.1 & 0.01 & 0.02 & 0.09 \\
\hline VS & 4.5 & 2.7 & 032 & 0.35 & 1.72 & 0.94 & 2.49 & 0.01 & 0.02 & 0.07 \\
\hline$B_{O}$ & 0.24 & 0.17 & 0.13 & 0.13 & 0.26 & 0.26 & 0.21 & 0.36 & 0.39 & 0.36 \\
\hline$M S_{(T, S, k)}(\%)$ & 75 & 75 & 25 & 25 & 90 & 5 & 5 & 100 & 100 & 100 \\
\hline
\end{tabular}
$\mathrm{CH}_{4} \cdot \mathrm{kg}^{-1} \mathrm{VS}$ excreted), and manure fraction $\left(M S_{(T, S, k)}\right)$ values for different animal species/categories. [11].

However, $E F$ used to estimate $\mathrm{CH}_{4}$ emissions related to manure management of animals ( $E F_{\text {manure }}$ ) was calculated following the Tier 2 method using Equation (3), and corresponding values are presented in Table 1:

$$
E F_{(T)}=\left(V S_{(T)} \times 365\right) \times\left[B_{O(T)} \times 0.67 \times \sum_{S, k}\left(\frac{M C F_{(S, k)}}{100} \times M S_{(T, S, k)}\right)\right]
$$

where $E F_{(T)}$ is the emission factor of $\mathrm{CH}_{4}$ from manure management of animal category/species $T\left(\mathrm{~kg} \mathrm{CH}_{4} \cdot\right.$ head $^{-1}$.year $\left.{ }^{-1}\right) ; V S_{(T)}$ is the daily amount of volatile solids excreted per animal of category $T$ (kg dry matter.animal ${ }^{-1}$.day $^{-1}$ ); 365 days per year ${ }^{-1}$ (the basis for calculating $V S$ annual production); $B_{O(T)}$ is the maximum capacity of $\mathrm{CH}_{4}$ production from manure produced by animal category $T\left(\mathrm{~m}^{3} \mathrm{CH}_{4}\right.$. 
$\mathrm{kg}^{-1}$ VS excreted); $0.67 \mathrm{~kg} \mathrm{~m}^{3}$ is a conversion factor of $\mathrm{m}^{3} \mathrm{CH}_{4}$ to $\mathrm{kg} \mathrm{CH}_{4} ; M C F_{(S, k)}$ is the methane conversion factor (\%) for each manure management system $S$ in the climatic region $k$; and $M S_{(T, S, k)}$ is the fraction (\%) of total manure from each animal category $T$ handled using manure management system $S$ in the climatic region $k$. The value for factor $M C F_{(S, k)}$ was $1.5 \%$, as proposed by IPCC [11], for regions where the average annual temperature is $24^{\circ} \mathrm{C}$ and excretions of animals waste on pastures are not managed.

\subsection{2. $\mathrm{N}_{2} \mathrm{O}$ Emissions from the Manure Management}

Nitrous oxide is either produced directly in manure by nitrification and denitrification processes, indirectly by nitrogen volatilization as ammonia and further deposition, and by manure nitrogen lixiviation. $\mathrm{N}_{2} \mathrm{O}$ emissions were calculated according to the IPCC Guidelines [11] as follows:

Direct $\mathrm{N}_{2} \mathrm{O}$ Emissions from the Manure Management $\left(\mathrm{N}_{2} \mathrm{O}_{\mathrm{D}}(\mathrm{MM})\right.$ )

Direct $\mathrm{N}_{2} \mathrm{O}$ emissions from manure management $\left(\mathrm{N}_{2} \mathrm{O}_{D(m m)}\right)$ were calculated according to the following equation:

$$
\mathrm{N}_{2} \mathrm{O}_{D(m m)}=\left[\sum_{S}\left[\sum_{T}\left(N_{(T)} \times N e x_{(T)} \times M S_{(T, S)}\right)\right] \times E F_{(S)}\right] \times \frac{44}{28}
$$

where $N_{(T)}$ is the number of animals of species/category $T\left(\mathrm{AAP}_{T}\right.$ from Equation (1)); $M S_{(T, S)}$ is the fraction of total annual nitrogen excretion for each animal species/category $T$ that was processed with manure management system $S$ (dimensionless, as proposed by [11], these values for each animal category were assumed to be equal to the fraction of manure from a livestock category with the manure management system in a climatic region $\left(M S_{(T, S, k)}\right)$ already provided in Table 1); and $N e x_{(T)}$ is the annual average nitrogen excretion per head of animal species/ category $T\left(\mathrm{~kg} \mathrm{~N} \cdot \mathrm{head}^{-1}\right.$.year $\left.{ }^{-1}\right)$, calculated as follows:

$$
\operatorname{Nex}_{(T)}=N_{\text {rate }(T)} \times \frac{T A M}{1000} \times 365
$$

where $N_{\text {rate(T) }}$ is the default nitrogen excretion rate $\left(\mathrm{kg} \mathrm{N.}(1000 \mathrm{~kg} \text { animal mass })^{-1}\right.$.day $\left.{ }^{-1}\right)$, and TAM is the typical animal mass for animal category T. Both values are provided in the IPCC 2006 Guidelines [11]. The values of the $\operatorname{Nex}_{(T)}$ for animals in developing countries are listed in Table 2. $E F_{(S)}$ is the default emission factor for direct $\mathrm{N}_{2} \mathrm{O}$ emissions from manure management system $S$ (Table 2); 44/28 is the conversion of $\mathrm{N}_{2} \mathrm{O}-\mathrm{N}$ emissions to $\mathrm{N}_{2} \mathrm{O}$ emissions.

\begin{tabular}{|c|c|c|c|c|c|c|c|c|c|c|}
\hline $\begin{array}{l}\text { Animal } \\
\text { Species }\end{array}$ & \multicolumn{2}{|c|}{ Cattle } & Sheep & Goats & \multicolumn{2}{|c|}{ Equines } & $\begin{array}{l}\text { Camelids } \\
\text { /Mules }\end{array}$ & \multicolumn{3}{|c|}{ Poultry } \\
\hline $\operatorname{Nrate}_{(T)}$ & 0.35 & 0.35 & 1.17 & 1.37 & 0.46 & 0.46 & 0.46 & 1.1 & 0.82 & 0.74 \\
\hline TAM & 550 & 391 & 28 & 30 & 238 & 130 & 217 & 0.9 & 1.8 & 6.8 \\
\hline $\operatorname{Nex}_{(T)}$ & 70.26 & 49.95 & 11.96 & 15.00 & 39.96 & 21.83 & 36.43 & 0.36 & 0.54 & 1.84 \\
\hline $\mathrm{N}_{2} \mathrm{O}_{D(m m)}$ & 0.41 & 0.29 & 0.02 & 0.03 & 0.28 & 0.01 & 0.01 & 0.001 & 0.001 & 0.003 \\
\hline
\end{tabular}

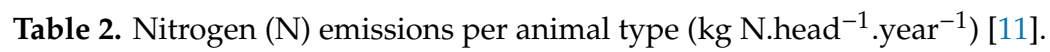

$\operatorname{Nrate}_{(T)}$ : default $\mathrm{N}$ excretion rate per day $\left(\mathrm{kg} \mathrm{N} .1000 \mathrm{~kg}^{-1}\right.$ animal mass.day $\left.{ }^{-1}\right)$; TAM: typical animal mass for an animal of type $T\left(\mathrm{~kg}\right.$ animal $\left.{ }^{-1}\right)$; $N e x_{(T)}$ : annual average $\mathrm{N}$ excretion per head of animal category $T$ per year

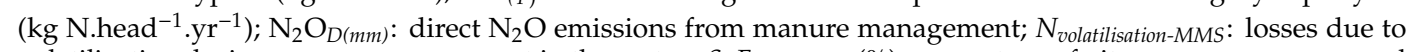
volatilization during manure management in the system $S$; Frac ${ }_{\text {Gas }}$ S $(\%)$ : percentage of nitrogen manure managed for animal species/category $T$, which is volatilized as $\mathrm{NH}_{3}$ and $\mathrm{NOx}$ in manure management $S$.

Indirect $\mathrm{N}_{2} \mathrm{O}$ Emissions due to $\mathrm{N}$ Volatilization during Manure Management $\left(\mathrm{N}_{2} \mathrm{OM}\right.$ (MMS))

$$
\mathrm{N}_{2} \mathrm{O}_{G(m m)}=\left(N_{\text {volatilisation-MMS }} \times E F_{M M S}\right) \times \frac{44}{28}
$$


where $\mathrm{N}_{2} \mathrm{O}_{G(m m)}$ is the indirect $\mathrm{N}_{2} \mathrm{O}$ emission due to $\mathrm{N}$ volatilization during manure management in $\mathrm{kg} \mathrm{N}_{2} \mathrm{O}$.year ${ }^{-1}, E F_{M M S}$ is the default emission factor for indirect $\mathrm{N}_{2} \mathrm{O}$ due to $\mathrm{N}$ volatilization during manure management from manure management system $S$ (the corresponding default emission factor value is 0.01 ), and $N_{\text {volatilization-MMS }}$ is the $\mathrm{N}$ losses due to volatilization during manure management in system $S$ and determined according to Equation (7), and values are given in Table 2:

$$
\mathrm{N}_{\text {volatilisation-MMS }}=\sum_{S}\left[\sum_{T}\left[\left(N_{(T)} \times \operatorname{Nex}_{(T)} \times M S_{(T, S)}\right) \times\left(\frac{\operatorname{Frac}_{G a s M S}}{100}\right)_{(T, S)}\right]\right]
$$

where $\mathrm{Frac}_{\text {Gas MS }}$ is the percentage (\%) of manure nitrogen for animal species/category $\mathrm{T}$, which volatilizes as $\mathrm{NH}_{3}$ and $\mathrm{NOx}$ in manure management system $\mathrm{S}$.

\subsection{Calculation}

The national inventory of Tunisian greenhouse gas emissions/removals was conducted in accordance with IPCC 2006 Guidelines [11] and covered all the direct gases listed by these guidelines. It also included indirect gases, referenced in EMEP (European Monitoring and Evaluation Programme)/EEA (European Environment Agency) air pollutant emission inventory guidebook.

The emissions are presented in original units (Gigagrams, $\mathrm{Gg}$ ) for all direct and indirect gases, but are also expressed in $\mathrm{Gg} \mathrm{CO}_{2}$ equivalent $\left(\mathrm{Gg} \mathrm{CO}_{2} \mathrm{e}\right)$, for all direct gases, by converting these direct gases according to their global warming potential (GWP). The GWPs used for direct GHGs in inventory development are assumed to be 25 for $\mathrm{CH}_{4}$ and 298 for $\mathrm{N}_{2} \mathrm{O}$ [13].

\section{Results}

\subsection{Livestock Population Distribution}

Analysis of recent surveys along the studied period (2008-2018) indicates a large diversity in the composition of the national livestock population (Table 3). Poultry accounts for more than 20 million heads in 2018, mainly from broilers (50\%). For the remaining population categories, sheep are the most dominant species, with an average of 6.5 million, followed by 1.2 million goats, 401 thousand dairy cattle, and 234 thousand other cattle in 2018. Camelids and equines (horses, donkeys, and mules) represent 214 thousand (2018). It is pertinent to also mention that, within cattle species, dairy cattle are the most dominant and account for $65 \%$.

Table 3. Average annual animal population (thousands) in Tunisia during the studied period (2008-2018). Based on data provided by the Tunisian Ministry of Agriculture [4] and applying Equation (1).

\begin{tabular}{|c|c|c|c|c|c|c|c|c|c|c|}
\hline \multirow{2}{*}{$\begin{array}{l}\text { Animal } \\
\text { Species }\end{array}$} & \multicolumn{2}{|c|}{ Cattle } & \multirow{2}{*}{ Sheep } & \multirow{2}{*}{ Goats } & \multicolumn{2}{|c|}{ Equines } & \multirow{2}{*}{$\begin{array}{l}\text { Camelids } \\
\text { Mules }\end{array}$} & \multicolumn{3}{|c|}{ Poultry } \\
\hline & Dairy & Others & & & Horses & Donkey/l & & Broiler & Laying & Turkey \\
\hline 2008 & 449 & 246 & 7301 & 1496 & 25 & 172 & 84 & 7536 & 6387 & 1654 \\
\hline 2009 & 443 & 239 & 7362 & 1455 & 24 & 168 & 82 & 7796 & 6358 & 1934 \\
\hline 2010 & 440 & 231 & 7234 & 1296 & 23 & 164 & 80 & 8662 & 6214 & 2278 \\
\hline 2011 & 430 & 226 & 6999 & 1282 & 23 & 164 & 80 & 8269 & 6200 & 1993 \\
\hline 2012 & 427 & 228 & 6802 & 1272 & 23 & 164 & 80 & 9766 & 6332 & 2888 \\
\hline 2013 & 424 & 222 & 6856 & 1274 & 22 & 156 & 78 & 10,649 & 6725 & 2851 \\
\hline 2014 & 438 & 234 & 6806 & 1248 & 22 & 148 & 76 & 11,307 & 7418 & 3059 \\
\hline 2015 & 450 & 231 & 6490 & 1162 & 21 & 139 & 78 & 11,807 & 9797 & 2917 \\
\hline 2016 & 458 & 228 & 6486 & 1199 & 21 & 130 & 80 & 10,899 & 7431 & 2811 \\
\hline 2017 & 437 & 209 & 6406 & 1185 & 20 & 120 & 81 & 10,836 & 7350 & 2892 \\
\hline 2018 & 401 & 194 & 6470 & 1197 & 20 & 111 & 83 & 10,993 & 6866 & 3033 \\
\hline
\end{tabular}


Except for poultry, the total numbers of all animal categories have generally followed a slight decrease ranging between $11 \%$ (dairy cattle and sheep), 21\% (other cattle), and $20 \%$ (goats) from 2008 to 2018. During the same period, poultry recorded an increase of about $34 \%$.

\subsection{Total Greenhouse Gas Emissions (GHGs)}

As depicted in Figure 1, total GHG emissions from Tunisian livestock decreased from $3076 \mathrm{Gg}$ $\left(\mathrm{CO}_{2} \mathrm{e}\right)$ in 2008 to $2695 \mathrm{Gg}\left(\mathrm{CO}_{2} \mathrm{e}\right)$ in 2018. A continuous decrease was observed from 2008 to 2013 (6.6\%) and from 2016 to 2018 (7.3\%).

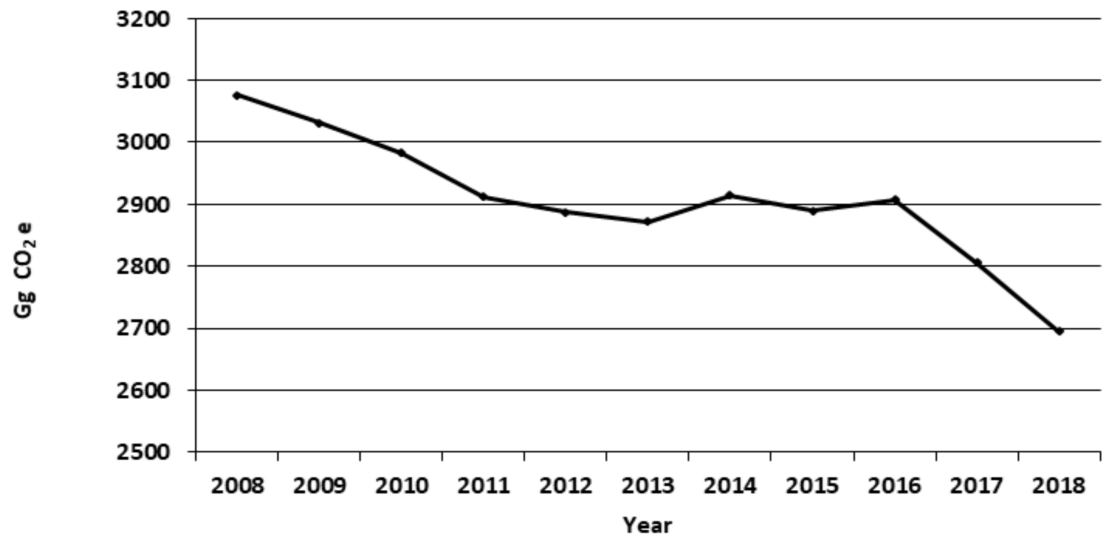

Figure 1. Evolution of total greenhouse gas emissions $\left(\mathrm{CH}_{4}\right.$ and $\left.\mathrm{N}_{2} \mathrm{O}\right)$ from the total Tunisian livestock $\left(\mathrm{Gg} \mathrm{CO}_{2} \mathrm{e}\right)$ throughout the studied period (2008-2018).

More than $50 \%$ of the total GHG emissions were from cattle (Figure 2), followed by sheep (32\%), goats $(7 \%)$, camelids $(3 \%)$, others $(3 \%)$, and poultry $(1 \%)$.

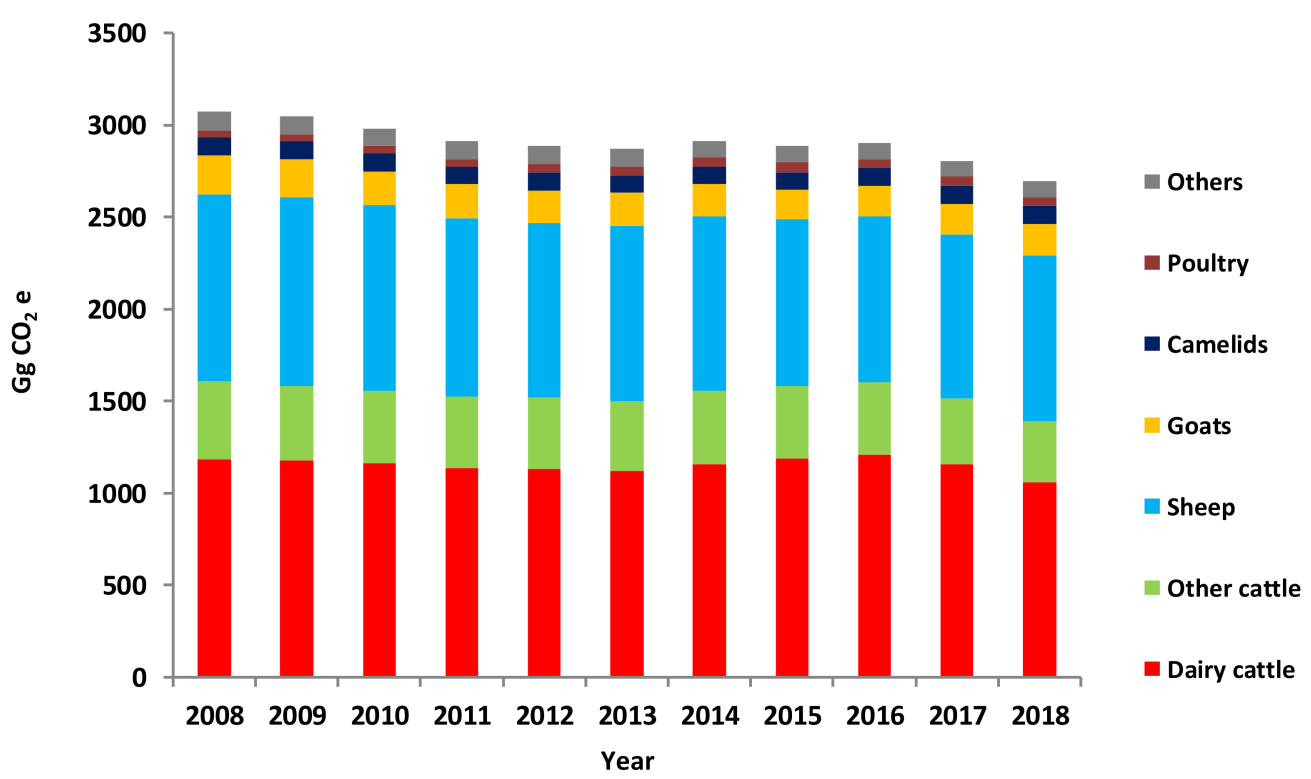

Figure 2. Evolution of the total gas emissions $\left(\mathrm{Gg} \mathrm{CO}_{2} \mathrm{e}\right)$ by the different animal species/category from Tunisian livestock during the studied period (2008-2018).

\subsection{Methane Emissions}

Figure 3 shows the estimated $\mathrm{CH}_{4}$ emissions from Tunisian livestock farming. $\mathrm{CH}_{4}$ represents about $92 \%$ of the total GHGs. Total $\mathrm{CH}_{4}$ emissions in 2008 were $113 \mathrm{Gg}$, or $2832 \mathrm{CO}_{2} \mathrm{e}$ (Figure 3) as 
determined using GWP for a 100-year time horizon from IPCC 2006 [11]. A steady decrease in total $\mathrm{CH}_{4}$ emissions was observed from 2008 onwards, so that emissions in 2018 were $13 \%$ lower than those estimated in 2008, mainly due to the decrease in $\mathrm{CH}_{4}$ from enteric fermentation (Figure 3). It is worth mentioning that about $85 \%$ of the total $\mathrm{CH}_{4}$ produced comes from enteric fermentation.

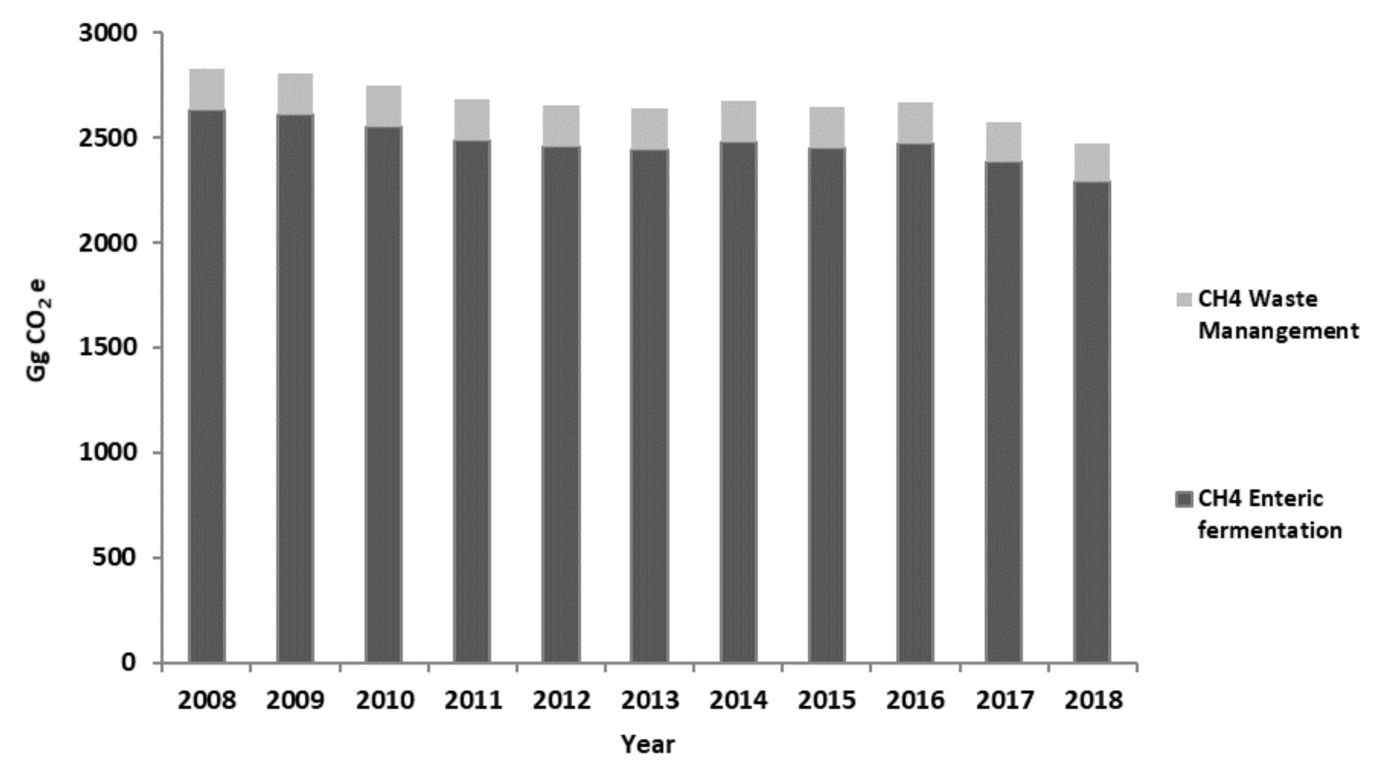

Figure 3. Evolution of the total $\mathrm{CH}_{4}$ emissions $\left(\mathrm{Gg} \mathrm{CO}_{2} \mathrm{e}\right)$ from total Tunisian livestock derived from either enteric fermentation or manure management during the studied period (2008-2018).

Cattle (dairy and others) and small ruminants (sheep and goats) are the first animal species producers of $\mathrm{CH}_{4}$, participating with more than $52 \%$ and $40 \%$ of the total $\mathrm{CH}_{4}$ emissions, respectively (Figure 4); these were followed by camelids and equines (horses, donkeys, and mules), which participated with less than $1 \%$ from the total $\mathrm{CH}_{4}$ emissions. $\mathrm{CH}_{4}$ emissions from poultry are considered negligible.

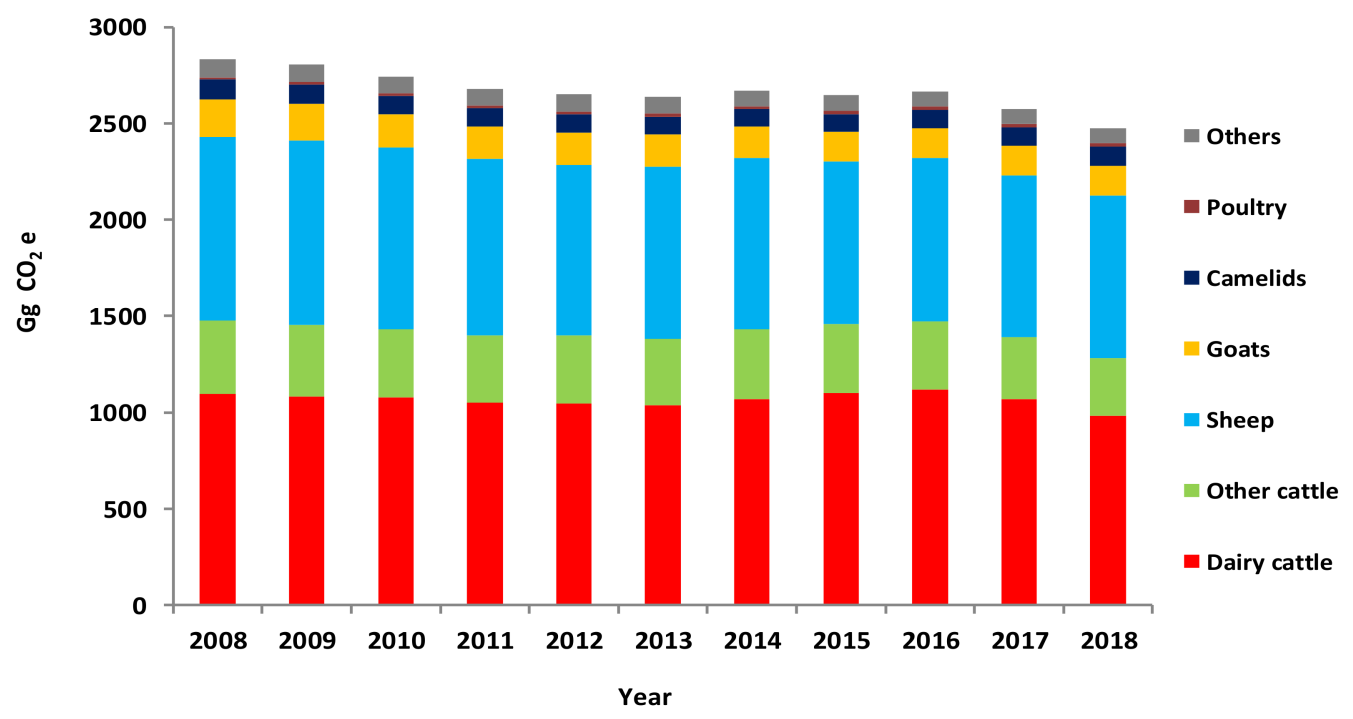

Figure 4. Evolution of total $\mathrm{CH}_{4}$ production $\left(\mathrm{Gg} \mathrm{CO}_{2} \mathrm{e}\right)$ by the different animal species/category from Tunisian livestock during the studied period (2008-2018). 
The same ranking was observed in $\mathrm{CH}_{4}$ derived from the enteric fermentation (Figure 5), as it represents the largest part of GHG emissions. The $\mathrm{CH}_{4}$ emissions are estimated at 78, 46, 5, and $5 \mathrm{~kg}$ $\mathrm{CH}_{4}$.head ${ }^{-1}$.year ${ }^{-1}$ for cattle, sheep, goats, and camelids, respectively.

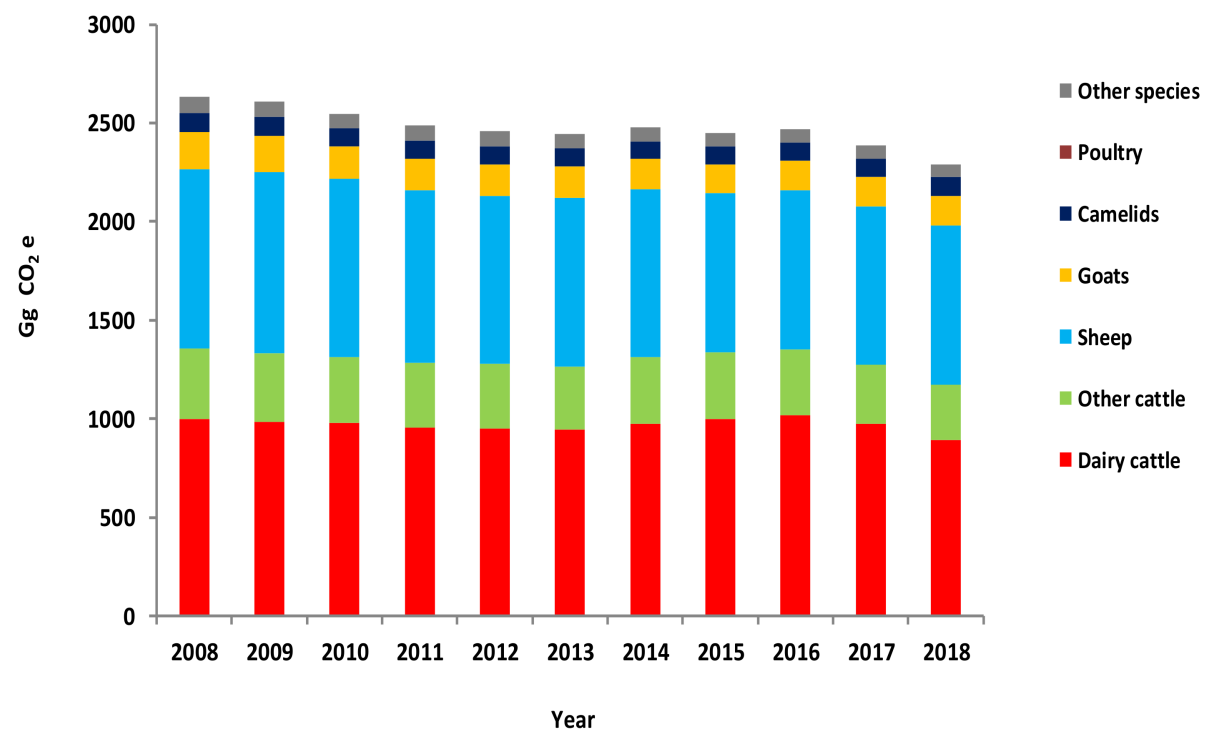

Figure 5. Evolution of $\mathrm{CH}_{4}$ emissions $\left(\mathrm{Gg} \mathrm{CO}_{2} \mathrm{e}\right)$ issued from the enteric fermentation by the different animal species/category from Tunisian livestock during the studied period (2008-2018).

\subsection{Nitrous Emissions}

Total nitrous emissions (direct and indirect $\mathrm{N}_{2} \mathrm{O}$ ) were low $\left(<250 \mathrm{Gg} \mathrm{CO}_{2} \mathrm{e}\right)$ and rather invariable within a narrow range during the studied period (Figure 6). They represent about $8 \%$ of the total GHG. Moreover, direct $\mathrm{N}_{2} \mathrm{O}$ emissions from manure represent about $60 \%$ of the total nitrous emissions.

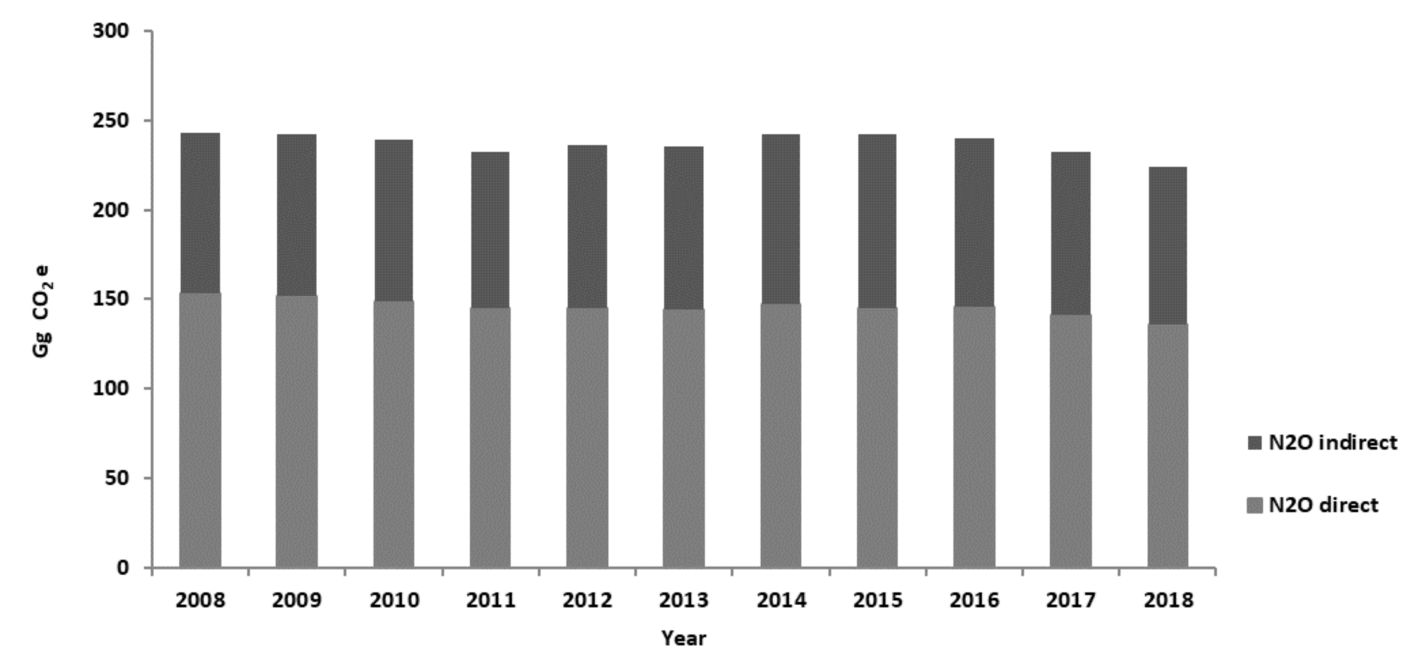

Figure 6. Evolution of direct and indirect $\mathrm{N}_{2} \mathrm{O}$ emissions $\left(\mathrm{Gg} \mathrm{CO}_{2} \mathrm{e}\right)$ from Tunisian livestock during the studied period (2008-2018).

Cattle (dairy and others) contribute with more than $50 \%$ of the total $\mathrm{N}_{2} \mathrm{O}$ emissions (Figure 7), followed by small ruminants $(>30 \%)$, poultry $(>10 \%)$, and other species $(<4 \%)$. 


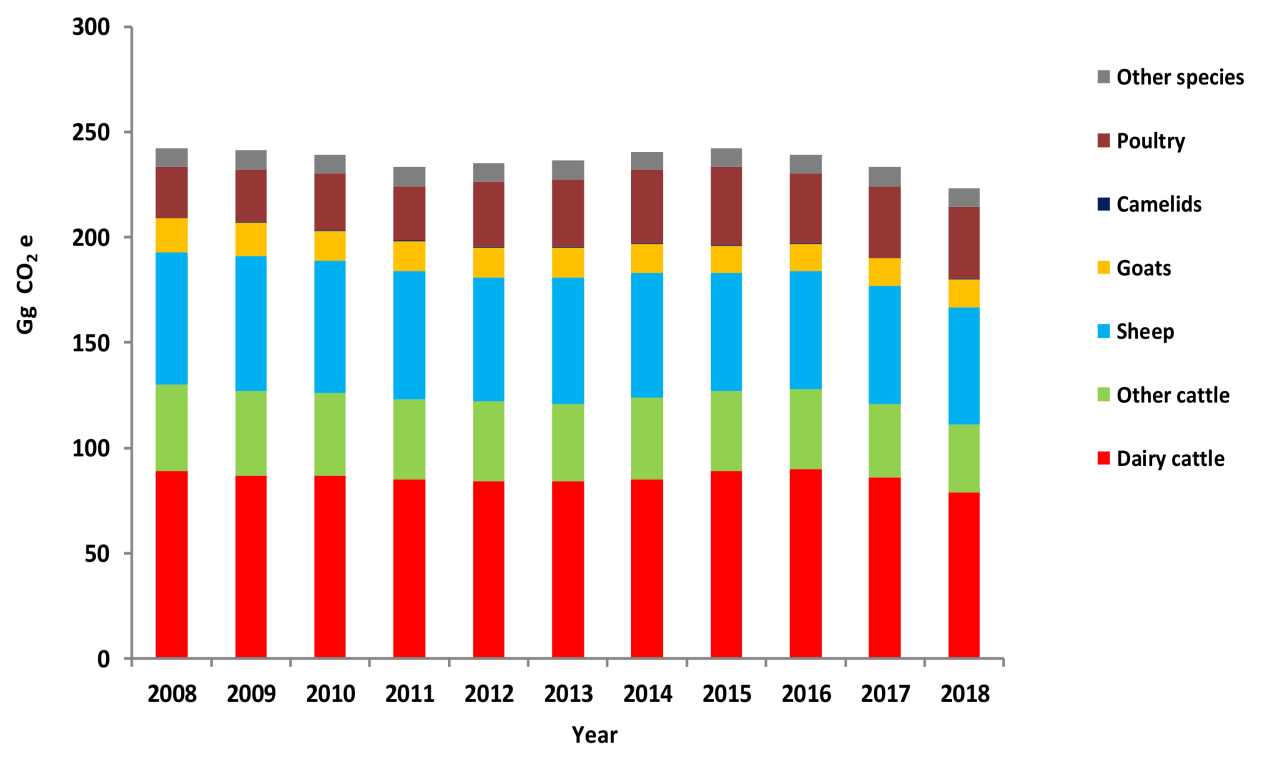

Figure 7. Evolution of $\mathrm{N}_{2} \mathrm{O}$ emissions $\left(\mathrm{Gg} \mathrm{CO}_{2} \mathrm{e}\right)$ by the different animal species/category from Tunisian livestock during the studied period (2008-2018).

\section{Discussions}

\subsection{Total GHG Emissions from Tunisian Livestock}

It is well established that livestock production contributes up to $14.5 \%$ of the world's annual anthropogenic GHG emissions [14,15]. From the calculations used in our study, it can be estimated that livestock emissions would contribute to $37 \%$ of the total $\mathrm{CH}_{4}$ and to $10 \%$ of the total $\mathrm{N}_{2} \mathrm{O}$ emissions reported in the last inventory of gross and net GHG emissions in Tunisia in 2012 [8,9]. Our estimations show some inconsistencies with the Tunisian 2012 GHG inventory [8,9], because these values unrealistically represent $100 \%$ and $12 \%$ of the $\mathrm{CH}_{4}$ and $\mathrm{N}_{2} \mathrm{O}$ emissions attributed to Tunisian AFOLU in 2012 [8,9], indicating that our $\mathrm{CH}_{4}$ emissions may be overestimated and $\mathrm{N}_{2} \mathrm{O}$ emissions underestimated when compared with the values communicated in 2012. It may be too speculative to conclude which values reflect reality more accurately, and the inconsistency should be interpreted considering the most likely different methods used for the estimations (not described in the 2012 inventory). Nevertheless, it seems clear that livestock is a main contributor to $\mathrm{CH}_{4}$ and a minor contributor to $\mathrm{N}_{2} \mathrm{O}$ total and AFOLU emissions in Tunisia.

GHG emissions derived from Tunisian livestock varied slightly, decreasing from 3076 to $2695 \mathrm{Gg}$ $\mathrm{CO}_{2} \mathrm{e}$ during the studied period (2008-2018). A continuous decrease of about $7 \%$ was noted between 2008-2013 and 2015-2018. This trend was expected as the size of the animal stock decreased in the same period (Table 3). Therefore, this declining trend has to be interpreted carefully because GHG emissions were based exclusively on the average annual population of each animal category, and other factors may influence the volume of the emissions. As animal production systems become more intensive, the animal numbers are decreased, but the feed intake and the amount of product obtained per head are increased, so it can be expected that the volume of gas emitted per animals will also be also increased. Therefore, the emission factors should be adjusted, introducing the likely impact on the total estimations of the weight of intensification of animal production on individual gas emissions.

Data reported from other countries show that emissions are directly related to the total livestock stock and agricultural production systems, thus emissions of $24,700 \mathrm{Gg} \mathrm{CO}_{2} \mathrm{e}$ have been estimated in India [16], of 13,046 Gg CO $2 \mathrm{e}$ in Algeria [17], and of $12,000 \mathrm{Gg} \mathrm{CO}_{2} \mathrm{e}$ in Vietnam [18]. The estimations also depend on the IPCC emission factors applied for each animal species in each studied country. It is also pertinent to mention that GWP of $\mathrm{CH}_{4}$ and $\mathrm{N}_{2} \mathrm{O}$ over one 100-year time horizon differs between the IPCC 1997 [19], IPCC 2013 [20], and UNFCCC [13]. In our study, IPCC 2006 [11] was followed 
as it is most commonly used in the literature for estimating livestock GHG emissions. The warming potential of $\mathrm{CH}_{4}$ was $25 \mathrm{CO}_{2} \mathrm{e}$, while $\mathrm{N}_{2} \mathrm{O}$ was $298 \mathrm{CO}_{2} \mathrm{e}$. These GWPs are lower than those considered by the latest IPCC 2013 [20], of $34 \mathrm{CO}_{2} \mathrm{e}$ for $\mathrm{CH}_{4}$ and $310 \mathrm{CO}_{2} \mathrm{e}$ for $\mathrm{N}_{2} \mathrm{O}$. The UNFCCC [13] stated that $\mathrm{CH}_{4}$ emissions have a GWP of $21 \mathrm{CO}_{2} \mathrm{e}$ and $\mathrm{N}_{2} \mathrm{O}$ of $310 \mathrm{CO}_{2}$ e over a 100 -year time horizon.

Moreover, a detailed analysis of our estimations in Tunisia indicates a mosaic in livestock composition, and it is expected that GHG emissions would show a large variability between animal species (Figure 2). Among categories, poultry followed by sheep and goats were the species with the higher number of individuals. Even though, cattle (dairy and other categories) are the highest contributors $(>50 \%)$ to GHG emissions (as expected considering the mass per animal, the number of animals in the country, and their rumination $\mathrm{CH}_{4}$ emissions), followed by sheep (32\%), goats $(7 \%)$, camelids ( $7 \%)$, equines (horses, donkeys, and mules; $7 \%)$, and poultry $(<2 \%)$. In line with our results, Gerber et al. [14] reported that beef and dairy cattle, accounting for $65 \%$ of the total livestock, are the species that produce the highest GHG emissions. Chhabra et al. [16] found that bovine (cattle and buffaloes) are the predominant contributors with $91 \%$ of GHG emissions in India, owing to their huge population in this country, followed by sheep, goats, and others. Likewise, a study conducted in Indonesia [21] reported that cattle are the major contributors to GHG emissions during the 2005-2015 period. However, a study published by Sallaye [17] in Algeria revealed that sheep were the first contributors to GHG emissions in that country, followed by dairy cattle, goats, and camelids. This could be due to the large population of Algerian sheep as compared with the other animal species.

Emission factors are a very critical element to the accuracy of the estimations in the calculations of emission per animal and could explain some of the variation among results reported in the literature. As compared with other animal species, the relatively high emissions derived from cattle, sheep, and goats could be explained by the prevalence of $\mathrm{CH}_{4}$ emissions from ruminal microbial fermentation, the imbalanced rations coupled with the low nutritive value of the feed available, as well as the lower efficiency and productivity of these animals in developing countries as compared with non-ruminants. This may be, probably, due to an excessive loss of nutrients, energy, and organic matter [11]. Therefore, GHG emissions from livestock farming seem to also be dependent on some external factors such as feeding practices, housing systems, and manure management systems $[14,15,18]$. In this context, it is suggested that, in order to obtain more accurate emissions' estimations, there is an urgent need to get a characterization of each animal species, livestock production system, data on the feed and ration composition for each animal species, and proportions of produced manure in each management system. Actually, these data are not currently well documented for emissions' inventory purposes in Tunisia. Improving the quantity and quality of databases and research related to livestock farming would be a useful tool to enhance emissions' monitoring in the livestock sector.

\subsection{Methane Emissions}

For ruminants, methanogenesis in the rumen is an essential metabolic process to maintain a steady state of fermentation as it scavenges the molecular hydrogen generated mainly during the carbohydrate fermentation process. $\mathrm{CH}_{4}$ is a natural by-product of the ruminant digestion process, acting as a hydrogen sink. Ruminal methanogenesis is influenced by animal species, age, management, and mainly by the quality and quantity of feedstuffs administered to the animals. $\mathrm{The} \mathrm{CH}_{4}$ production resulting from enteric fermentation contributes about $20 \%$ of the total global $\mathrm{CH}_{4}[15,22]$. It is well established that the countries with the highest contribution of $\mathrm{CH}_{4}$ emissions related to livestock production are India, China, Brazil, and the United States [23-25].

In our study, GHG emissions from Tunisian livestock were mainly as $\mathrm{CH}_{4}(92 \%)$ as compared with $\mathrm{N}_{2} \mathrm{O}(8 \%)$ (Figure 3). Chhabra et al. [16] reported total GHG emissions from Indian livestock of about $247,200 \mathrm{Gg} \mathrm{CO}_{2} \mathrm{e}$, with $\mathrm{CH}_{4}$ representing $99.8 \%$ and $\mathrm{N}_{2} \mathrm{O}$ emissions only $0.2 \%$. Similarly, Moeletsi et al. [26] reported a high contribution $(>90 \%)$ of $\mathrm{CH}_{4}$ emissions versus $\mathrm{N}_{2} \mathrm{O}(10 \%)$ from the South African livestock. The relative contribution of each gas to the total emissions may differ slightly owing to differences among countries in the livestock numbers or in the farming and manure 
management practices and, therefore, in the emission factors used in each case. In this study, dairy cattle were the highest contributors to total $\mathrm{CH}_{4}$ production $(40 \%)$, followed by sheep (34\%), other cattle $(13 \%)$, goats $(7 \%)$, and camelids (4\%). However, a study on Algerian livestock's GHG emissions [17] reported that sheep, the most important livestock in that country, were the highest contributors of $\mathrm{CH}_{4}$ produced from enteric fermentation (53\%), followed by dairy cattle (29\%), goats (9\%), and camelids (6\%). The amount of $\mathrm{CH}_{4}$ emissions depends not only on the number of animals of each species, but also on other factors such as ruminant breed, type of production (dairy or meat), diet quality influencing ruminal microbiota and fermentation processes [15,27], and production systems and regional characteristics (e.g., climate and landscape) [11]. In this context, Food and Agriculture Organization (FAO) [28] reported that confined systems would increase $\mathrm{CO}_{2}$ emissions because of greater fossil fuel use and relatively less use of solar energy. In Tunisia, $40 \%$ of total milk, $20 \%$ of red meat (mostly cattle), and more than $80 \%$ of white meat and eggs (poultry) are produced in intensive systems. Moreover, higher individual $\mathrm{CH}_{4}$ emissions were recorded in cattle $\left(78 \mathrm{~kg} \cdot \mathrm{year}^{-1}\right.$.head $\left.{ }^{-1}\right)$, followed by camelids $\left(46 \mathrm{~kg} \cdot \mathrm{year}^{-1}\right.$.head ${ }^{-1}$ ), equines (horses, donkeys, and mules: $16 \mathrm{~kg} \cdot \mathrm{head}^{-1} \cdot \mathrm{year}^{-1}$ ), sheep $\left(5 \mathrm{~kg}\right.$. head ${ }^{-1} \cdot$ year $\left.^{-1}\right)$, and goats $\left(5 \mathrm{~kg}\right.$. head ${ }^{-1} \cdot$ year $\left.^{-1}\right)$. Lower emissions were recorded in developed countries [29], where the average individual $\mathrm{CH}_{4}$ emissions were reported to be 55, 50, 8 , and $5 \mathrm{~kg}$.head ${ }^{-1}$.year ${ }^{-1}$ for cows, buffalo, sheep, and goats, respectively. Negligible emissions of $\mathrm{CH}_{4}(0.4 \%)$ are expected from poultry, being generated mostly from manure management. In Africa, it is estimated that $\mathrm{CH}_{4}$ emissions will increase by about $42 \%$ in $2030\left(11,100 \mathrm{Gg}\right.$ of $\mathrm{CH}_{4}$.year $\left.{ }^{-1}\right)$ as compared with production in $2000\left(7800 \mathrm{Gg}\right.$ of $\mathrm{CH}_{4}$. year $\left.{ }^{-1}\right)$. This is related to the expected increase in the livestock population owing to the increasing demand for foods of animal origin. If such a positive correlation between livestock population and $\mathrm{CH}_{4}$ emissions follows continuously, it would be expected that global $\mathrm{CH}_{4}$ emissions would increase by $60 \%$ by 2030 [30]. Reports from FAO [28,31] have revealed that, worldwide, enteric fermentation and manure storage emissions have been increasing for the main livestock species. Nevertheless, the adoption of suitable feeding practices and comprehensive manure and nutrients' management could significantly reduce methane emissions [32,33].

During the animal digestive process, the enteric fermentation converts the ingested feed into digestible feed and releases $\mathrm{CH}_{4}$ through belching [24,34]. Therefore, this end product is considered as an energy loss $[15,22]$ and represents the second-largest source of emissions (39\% in the total GHG) after feed production and processing, followed by manure storage (10\% of the total GHG) and processing and transportation of animal products (6\%). In our study, enteric fermentation accounted for $85 \%$ of the total $\mathrm{CH}_{4}$ emissions, predominately generated from cattle and sheep. These emissions could be reduced if feed composition, feed intake, and feed energy content are modified $[35,36]$ by formulating rations that are more balanced or using feed additives. In line with these suggestions, Dourmad et al. [37] and Yan et al. [38] suggested that increasing the feed energy value could reduce methane emissions.

Contrary to the high contribution from enteric fermentation, manure management accounted only for $7 \%$ of total GHGs and $15 \%$ of total $\mathrm{CH}_{4}$ livestock emissions, ranging from 181 to $200 \mathrm{Gg} \mathrm{CO}_{2} \mathrm{e}$ during the studied period (2008-2018). Similar importance of enteric fermentation was observed earlier on Indian [16] and Algerian [17] livestock. The results reported on GHG production from Vietnam's livestock [18] revealed that $\mathrm{CH}_{4}$ emissions from enteric fermentation and manure management were at the same order of magnitude.

On the other hand, it is pertinent to note that bovines, particularly dairy cattle, contributed the bulk of the methane emission from enteric fermentation (52\%), followed by sheep (35\%), goats $(6 \%)$, and camelids (3\%). The main reason for the highest emissions issued from cattle, mainly dairy cattle, recorded in our present study is attributed to the high population of this species coupled with a relatively high EF used (89 kg.head ${ }^{-1} \cdot$ year $^{-1}$ for dairy cattle and $63 \mathrm{~kg}$.head ${ }^{-1}$.year ${ }^{-1}$ for non-dairy cattle). Truong et al. [18] noted a large contribution of cattle $\mathrm{CH}_{4}$ from enteric fermentation. Moeletsi et al. [26] found that, in South Africa, methane from enteric fermentation in dairy cattle 
contributed less to the total methane emission than non-dairy cattle and sheep. It appears, therefore, that EF is a critical element to the accuracy of estimations in emissions' inventory.

Patra [39] and Moeletsi et al. [26] estimated enteric $\mathrm{CH}_{4}$ emissions using Tier 1 methodology in India and South Africa, respectively, and obtained rates of animal contributions that are widely different from those reported in the current study. Such differences could be due to the animal species and herd composition, and the approach followed for the calculation. In this context, Moeletsi et al. [26] reported that, as compared with Tier 1 methodology, utilization of country-specific emission factors gave rise to an increase of total $\mathrm{CH}_{4}$ emissions from enteric fermentation by about $37 \%$. It appears, therefore, that the uncertainty in the Tier 1 method is high [40]. This would be expected if we bear in mind that the emission factors are not based on country-specific conditions, and the activity data used in this approach include data from non-intensive agricultural countries [6,40]. However, in developed countries, the IPCC default values can overestimate emissions of some sections of the livestock population $[40,41]$. Considering these variations and discrepancies, IPCC has encouraged the derivation and use of specific-for-purpose emission factors to provide more accurate estimations of the emissions from each country [41].

\subsection{Nitrous Oxide Emissions}

Besides methane, Tunisian livestock also contributed a small amount of annual $\mathrm{N}_{2} \mathrm{O}$ emissions, ranging between 224 (2008) and $243 \mathrm{Gg} \mathrm{CO}_{2} \mathrm{e}$ (2018), which can have some impact on the total GHGs. Nitrogenous emissions, as compared with enteric $\mathrm{CH}_{4}$, are considered low and are usually neglected. If we bear in mind that the GWP of this compound is more than ten times greater than that of $\mathrm{CH}_{4}$, then even a small amount should not be disregarded.

Moreover, our results indicated that cattle contributed almost $60 \%$ of the total $\mathrm{N}_{2} \mathrm{O}$ emissions, followed by sheep $(<30 \%)$, poultry $(<8 \%)$, goats $(<8 \%)$, and the other species $(<4 \%)$. In South, Southeast, and East Asia, the inventories for $\mathrm{N}_{2} \mathrm{O}$ and $\mathrm{CH}_{4}$ emissions from animal farming revealed that cattle, compared with other animal species, were the highest producers of $\mathrm{CH}_{4}(56 \%)$ and $\mathrm{N}_{2} \mathrm{O}(30 \%)$. Chhabra et al. [16] estimated that poultry was the first contributor (86.1\%) to the total $\mathrm{N}_{2} \mathrm{O}$ emissions, followed by pigs $(7.3 \%)$, indigenous cattle $(5.7 \%)$, and exotic cattle (1.0\%). Similarly, Truong et al. [18] reported that poultry accounted for the largest share of $\mathrm{N}_{2} \mathrm{O}$ emissions $(60 \%)$, followed by pigs $(26 \%)$.

Differences among countries can be attributed to the different environmental conditions, herd size of each animal species, type and duration of waste management, and husbandry systems in each country [15,18]. In this context, Rotz [36], Dourmad et al. [37], and Dijkstra et al. [42] suggested that the amount of $\mathrm{N}_{2} \mathrm{O}$ emissions might be related to the nitrogen concentration in the diet and the dry matter ingested by the animal. The efficiency of feed conversion into animal products depends on the relative contributions of maintenance and production to the total requirement [37]. When animal production level is low, maintenance contributes more, resulting in more feed required per kg product and, consequently, in higher relative emissions. In meat-producing animals, the efficiency is also affected by the composition of the meat, as fat deposition requires more energy than protein retention in lean tissues [37].

\subsection{Mitigation and Adaptation Plan Undertaken by the Government}

Tunisia is aware of the impact of GHG emissions on the climate crisis and has adopted a proactive policy in terms of both mitigation and adaptation. One of the objectives of this policy is to implement nationally appropriate mitigation actions (NAMAs) in the livestock sector. With the support of several international organizations (United Nations Development Programme (UNDP), Global Environment Facility (GEF), German cooperation), a number of NAMA initiatives have been launched in Tunisia and are at various stages of development. As part of the baseline and mitigation scenarios determination, 2010 was defined as the reference year, and 2030 as the horizon year. The mitigation objective requires a total investment of up to 17.5 billion U.S. dollars over the period 2015-2030, with $85 \%$ of this amount allocated for the energy sector and 5\% for the livestock sector. In the agricultural sector, preliminary 
actions aiming at GHG mitigation include promotion of biological agriculture and reduction of pollution caused by the use of chemical fertilizers in excess in some intensive crops, stepping up the role of legumes in arable land, and the conservation and planting of biomass. GHG mitigation options related to animal management include the improvement of animal genetics, fertility, feeding, animal health, and longevity. Appropriate inventories of GHG emissions from each animal species farmed are required for all these measures to be effective. Given the new political environment of many countries and increased expectations of local communities, a general orientation to systematically focus on accessible or feasible adaptation options at low cost is necessary [6,35]. A series of adaptation measures have been undertaken, including adapting irrigated crops in the central regions, adapting mixed farming-livestock production to climate change in vulnerable regions, and updating the agricultural map to take into account the impacts of climate change. Other measures include the introduction of a climate monitoring and early warning system, an insurance mechanism against climatic hazards due to climate change, conserving and exploiting genetic heritage to adapt cereal crops to climate change, and developing innovative methods for arable crops.

\section{Conclusions and Perspectives}

This study revealed that, among the main livestock species farmed, cattle followed by small ruminants were responsible for the largest share of $\mathrm{CH}_{4}$ livestock emissions in Tunisia. Other species (equines and poultry) had a combined contribution of less than $2 \%$. The critical influence of the values assumed for each emission factor reveals that there is a need for more accurate coefficients, specific for each geographic region or for identifiable farming systems. Hence, there are urgent needs to understand the various factors affecting the variability in enteric $\mathrm{CH}_{4}$ production, to reduce the uncertainty in GHG emission inventories, and to identify viable strategies for GHG reduction from livestock. A slight decline in GHG emissions from livestock has been observed in Tunisia from 2008 to 2018 , concurrently with the decrease in the average population numbers of ruminants and equines, the main contributors to methane emissions. The estimation of GHG emissions is based exclusively on animal numbers, not taking into account that emissions per head can be increased as animal productivity is improved. In the future, worldwide emissions are expected to increase substantially as a response to an increasing demand for animal products. This can only be achieved by increasing animal productivity, even though the number of animals farmed is not increased or is even decreased slightly, as in Tunisia. These aspects need to be considered to refine the factors used for estimating GHG emissions more accurately, and priority should be given to creating an appropriate database for GHG inventory to facilitate the study of livestock contribution to GHG emissions. Once a more reliable inventory of GHG emissions from livestock is available, the formulation of appropriate adaptation and mitigation options with low costs for the agricultural sector is urgently required to be ready for adoption by farmers. In a broad sense, options for the mitigation of GHG emissions from the agricultural sector can be seen from the supply side as well as from the demand side. For supply-based measures, strategies lead to an increase in net GHG efficiency of agricultural production. These measures can be further defined as either technical or structural options. Whereas technical options reduce agricultural emissions using technologies such as anaerobic digesters, feed supplements, and soil nitrogen inhibitors, structural measures usually refer to more fundamental improvements such as a transition towards high-intensity management systems or relocation of production across regions. For demand-based measures, these options aim to reduce consumption of GHG-intensive products and at the reduction of waste. The improvement of animal productivity was also planned by the society as an efficient way to increase the production of animal products and meet the increasing local demand, without increasing the use of land or the emission of GHGs. Some other mitigation options, such as the use of feed additives in animal nutrition or of additives to enhance composting or for manure treatment, can be explored as an efficient strategy that may significantly reduce the GHG emissions per-unit-of-product footprint. 
Author Contributions: Conceptualization, H.A., S.L. and H.H.; Data curation, H.A. and S.L.; Formal analysis, H.A., S.L. and H.H.; Investigation, H.A., S.A., M.A., N.M. and R.B.; Methodology, H.H.; Resources, H.H.; Supervision, H.A.; Validation, H.A., M.H.A., N.M., M.E.d.M., M.C., R.B. and S.L.; Visualization, H.A. and H.H.; Writing—original draft, H.A.; Writing—review \& editing, H.A., N.M., M.E.d.H.M., M.C., S.L. and H.C.M. All authors have read and agreed to the published version of the manuscript.

Funding: This research was partly supported by the CLCA project, Phase II (Use of conservation agriculture in crop-livestock systems in the drylands for enhanced water use efficiency, soil fertility and productivity in NENA and LAC countries), which is funded by the International Fund for Agricultural Development (IFAD) (ICARDA's agreement $\mathrm{N}^{\circ}$ 200116).

Acknowledgments: In this section you can acknowledge any support given which is not covered by the author contribution or funding sections. This may include administrative and technical support, or donations in kind (e.g., materials used for experiments).

Conflicts of Interest: The authors declare no conflict of interest.

\section{References}

1. Diao, X.; Hazell, P.; Thurlow, J. The role of agriculture in African development. World Dev. 2010, 38, 1375-1383. [CrossRef]

2. African Union Development Agency-NEPAD (AUDA-NEPAD). African Agriculture, Transformation and Outlook (2013). Available online: https://web.archive.org/web/20201016205723/; https://www.nepad.org/ caadp/publication/agriculture-africa-transformation-and-outlook (accessed on 16 October 2020).

3. Santos, N.; Ceccacci, I. Egypt, Jordan, Morocco and Tunisia: Key Trends in The Agrifood Sector; Food and Agriculture Organization of the United Nations (FAO): Rome, Italy, 2015.

4. Observatoire National de l'Agriculture (ONAGRI). Annuaire Statistique 2017; ONAGRI, Ministère de l'Agriculture, des Ressources Hydrauliques et de la Pêche: Tunis, Tunisia, 2017.

5. Tubiello, F.N.; Salvatore, M.; Ferrara, A.F.; House, J.; Federici, S.; Rossi, S.; Biancalani, R.; Condor Golec, R.D.; Jacobs, H.; Flammini, A.; et al. The contribution of agriculture, forestry and other land use activities to global warming, 1990-2012. Glob. Chang. Biol. 2015, 21, 2655-2660. [CrossRef] [PubMed]

6. Wilkes, A.; Reisinger, A.; Wollenberg, E.; Van Dijk, S. Measurement, Reporting and Verification of Livestock GHG Emissions by Developing Countries in the UNFCCC: Current Practices and Opportunities for Improvement; CCAFS Report No. 17; CGIAR Research Program on Climate Change, Agriculture and Food Security (CCAFS) and Global Research Alliance for Agricultural Greenhouse Gases (GRA): Wageningen, The Netherlands, 2017.

7. Ministère des Affaires Locales et L'Environnement de la Tunisie. Conference of the Parties to the United Nations Framework Convention on Climate Change (UNFCCC)-Intended Nationally Determined Contribution: Tunisia (2015). Available online: https://web.archive.org/web/ 20181217172822/; https:/www4.unfccc.int/sites/ndcstaging/PublishedDocuments/TunisiaFirst/INDC-TunisiaEnglishVersion.pdf (accessed on 17 December 2018).

8. Ministère des Affaires Locales et L'Environnement de la Tunisie. Deuxième Rapport Biennal de la Tunisie (2016) à la Convention Cadre des Nations Unies sur les Changements Climatiques (CCNUCC). Available online: https://web.archive.org/web/20191114003609/; https://unfccc.int/sites/default/files/resource/BUR2_ Tunesia_2016.pdf (accessed on 14 November 2019).

9. Ministère des Affaires Locales et L'Environnement de la Tunisie/United. United Nations Develpment Programme-Global Evironmental Finance. Tunisia's Third National Communication (2019) as part of the United Nations Framework Convention on Climate Change (UNFCCC). Available online: https://web. archive.org/web/20201017061222/; https:/unfccc.int/sites/default/files/resource/SyntheseAngFinaliseTunisia. pdf (accessed on 17 October 2020).

10. Smith, P.; Bustamante, M.; Ahammad, H.; Clark, H.; Dong, H.; Elsiddig, E.A.; Haberl, H.; Harper, R.; House, J.; Jafari, M.; et al. Agriculture, Forestry and Other Land Use (AFOLU). In Climate Change 2014: Mitigation of Climate Change. Contribution of Working Group III to the Fifth Assessment Report of the Intergovernmental Panel on Climate Change; Edenhofer, O., Pichs-Madruga, R., Sokona, Y., Farahani, E., Kadner, S., Seyboth, K., Adler, A., Baum, I., Brunner, S., Eickemeier, P., et al., Eds.; Cambridge University Press: Cambridge, UK; New York, NY, USA, 2015; pp. 811-922. 
11. Intergovernmental Panel on Climate Change (IPCC). 2006 IPCC Guidelines for National Greenhouse Gas Inventories. In IPCC National Greenhouse Gas Inventories Programme; Eggleston, H.S., Buendia, L., Miwa, K., Ngara, T., Tanabe, K., Eds.; Institute for Global Environmental Strategies (IGES): Hayama, Japan, 2006; ISBN 4-88788-032-4.

12. Verner, D.; Treguer, D.; Redwood, J.; Christensen, J.; McDonnell, R.; Elbert, C.; Konishi, Y. Climate Variability, Drought, and Drought Management in Tunisia's Agricultural Sector; World Bank Group: Washington, DC, USA, 2018.

13. United Nations Climate Change. Global Warming Potentials (IPCC Fourth Assessment Report, 2007). Available online: https:/unfccc.int/process-and-meetings/transparency-and-reporting/greenhouse-gas-data/frequentlyasked-questions/global-warming-potentials-ipcc-fourth-assessment-report (accessed on 2 May 2020).

14. Gerber, P.J.; Steinfeld, H.; Henderson, B.; Mottet, A.; Opio, C.; Dijkman, J.; Falcucci, A.; Tempio, G. Tackling Climate Change Through Livestock-A Global Assessment of Emissions and Mitigation Opportunities; Food and Agriculture Organization of the United Nations (FAO): Rome, Italy, 2013; ISBN 978-92-5-107920-1.

15. Hristov, A.N.; Oh, J.; Firkins, J.L.; Dijkstra, J.; Kebreab, E.; Waghorn, G.; Makkar, H.P.S.; Adesogan, A.T.; Yang, W.; Lee, C.; et al. Mitigation of methane and nitrous oxide emissions from animal operations: I. A review of enteric methane mitigation options. J. Anim. Sci. 2013, 91, 5045-5069. [CrossRef] [PubMed]

16. Chhabra, A.; Manjunath, K.R.; Panigrahy, S.; Parihar, J.S. Greenhouse gas emissions from Indian livestock. Clim. Chang. 2013, 117, 329-344. [CrossRef]

17. Sallaye, M. Etablissement D'un Rapport sur L'inventaire des Sources D'émission et des Puits D’absorption de GES (2018). Available online: https://web.archive.org/web/20201018063956/; https://www.researchgate.net/profile/Miloud_Sallaye/publication/327872220_Etablissement_d\%27un_ rapport_sur_1\%27inventaire_des_sources_d\%27emission_et_des_puits_d\%27absorption_de_GES_ en_Algerie/links/5baaaf9b45851574f7e63b5c/Etablissement-dun-rapport-sur-linventaire-des-sourcesdemission-et-des-puits-dabsorption-de-GES-en-Algerie.pdf (accessed on 18 October 2020).

18. Truong, A.H.; Kim, M.T.; Nguyen, T.T.; Nguyen, N.T.; Nguyen, Q.T. Methane, nitrous oxide and ammonia emissions from livestock farming in the Red River Delta, Vietnam: An inventory and projection for 2000-2030. Sustainability 2018, 10, 3826. [CrossRef]

19. Intergovernmental Panel on Climate Change (IPCC). Revised 1996 IPCC Guidelines for National Greenhouse Inventories; Houghton, J.T., Meira Filho, L.G., Lim, B., Tréanton, K., Mamaty, I., Bonduki, Y., Griggs, D.J., Callander, B.A., Eds.; IPCC/OECD/IEA: Paris, France, 1997.

20. Intergovernmental Panel on Climate Change (IPCC). Climate Change 2013: The Physical Science Basis. Contribution of Working Group I to the Fifth Assessment Report of the Intergovernmental Panel on Climate Change; Stocker, T.F., Qin, D., Plattner, G.-K., Tignor, M., Allen, S.K., Boschung, J., Nauels, A., Xia, Y., Bex, V., Midgley, P.M., Eds.; Cambridge University Press: Cambridge, UK; New York, NY, USA, 2013; ISBN 978-1-107-05799-1.

21. Nugrahaeningtyas, E.; Baek, C.Y.; Jeon, J.H.; Jo, H.J.; Park, K.H. Greenhouse gas emission intensities for the livestock sector in Indonesia, based on the national specific data. Sustainability 2018, 10, 1912. [CrossRef]

22. Moss, A.R.; Jouany, J.P.; Newbold, J. Methane production by ruminants: Its contribution to global warming. Anim. Res. 2000, 49, 231-253. [CrossRef]

23. International Energy Agency (IEA) Part III: Greenhouse-gas emissions. $\mathrm{CO}_{2}$ Emissions from Fuel Combustion 2012; OECD Publishing: Paris, France, 2012; pp. III.1-III.51.

24. Thorpe, A. Enteric fermentation and ruminant eructation: The role (and control?) of methane in the climate change debate. Clim. Chang. 2009, 93, 407-431. [CrossRef]

25. Chang, J.; Peng, S.; Ciais, P.; Saunois, M.; Dangal, S.R.S.; Herrero, M.; Havlík, P.; Tian, H.; Bousquet, P. Revisiting enteric methane emissions from domestic ruminants and their $\delta^{13} \mathrm{CCH}_{4}$ source signature. Nat. Commun. 2019, 10, 1-14. [CrossRef] [PubMed]

26. Moeletsi, M.E.; Tongwane, M.I.; Tsubo, M. Enteric methane emissions estimate for Livestock in South Africa for 1990-2014. Atmos. Basel 2017, 8, 69. [CrossRef]

27. Knapp, J.R.; Laur, G.L.; Vadas, P.A.; Weiss, W.P.; Tricarico, J.M. Enteric methane in dairy cattle production: Quantifying the opportunities and impact of reducing emissions. J. Dairy Sci. 2014, 97, 3231-3261. [CrossRef] [PubMed]

28. Food and Agriculture Organization of the United Nations. Livestock's Long Shadow: Environmental Issues and Options; FAO: Rome, Italy, 2006; ISBN 978-92-5-105571-7. 
29. Sejian, V.; Lal, R.; Lakritz, J.; Ezeji, T. Measurement and prediction of enteric methane emission. Int. J. Biometeorol. 2011, 55, 1-16. [CrossRef] [PubMed]

30. Bruinsma, J. World Agriculture: Towards 2015/2030. An FAO Perspective; Earthscan Publications Ltd.: London, UK, 2003; ISBN 92-5-104835-5.

31. Food and Agriculture Organization of the United Nations (FAO). Livestock Sector Development for Poverty Reduction: An Economic and Policy Perspective—Livestock's Many Virtues; Otte, J., Costales, A., Dijkman, J., Pica-Ciamarra, U., Robinson, T., Ahuja, V., Ly, C., Roland-Holst, D., Eds.; FAO: Rome, Italy, 2012; ISBN 9789251072424.

32. Thornton, P.K.; Herrero, M. The Inter-Linkages Between Rapid Growth in Livestock Production, Climate Change, and The Impacts on Water Resources, Land Use, and Deforestation; International Livestock Research Institute (ILRI): Nairobi, Kenya, 2009.

33. Thornton, P.K.; Herrero, M. Potential for reduced methane and carbon dioxide emissions from livestock and pasture management in the tropics. Proc. Natl. Acad. Sci. USA 2010, 107, 19667-19672. [CrossRef] [PubMed]

34. Beauchemin, K.A.; McAllister, T.A.; McGinn, S.M. Dietary mitigation of enteric methane from cattle. CAB Rev. Perspect. Agric. Vet. Sci. Nutr. Nat. Resour. 2009, 4, 35.1-35.17. [CrossRef]

35. Hristov, A.N.; Oh, J.; Lee, C.; Meinen, R.; Montes, F.; Ott, T.; Firkins, J.; Rotz, A.; Dell, C.; Adesogan, A.; et al. Mitigation of greenhouse gas emissions in livestock production-A review of technical options for non- $\mathrm{CO}_{2}$ emissions. In FAO Animal Production and Health Paper No. 177; Gerber, P.J., Benjamin, H., Makkar, H.P.S., Eds.; FAO: Rome, Italy, 2013; ISBN 978-92-5-107659-0.

36. Rotz, C.A. Modeling greenhouse gas emissions from dairy farms. J. Dairy Sci. 2018, 101, 6675-6690. [CrossRef] [PubMed]

37. Dourmad, J.-Y.; Rigolot, C.; van de Werf, H. Emission of green house gas, developing management and animal farming systems to assist mitigation. In Livestock and Global Climate Change; Rowlinson, P., Steele, M., Nefzaoui, A., Eds.; British Society of Animal Science, Cambridge University Press: Hammamet, Tunisia, 2008; pp. 36-39.

38. Yan, T.; Agnew, R.; Gordon, F.; Porter, M. Prediction of methane energy output in dairy and beef cattle offered grass silage-based diets. Livest. Prod. Sci. 2000, 64, 253-263. [CrossRef]

39. Patra, A.K. A meta-analysis of the effect of dietary fat on enteric methane production, digestibility and rumen fermentation in sheep, and a comparison of these responses between cattle and sheep. Livest. Sci. 2014, 162, 97-103. [CrossRef]

40. Hristov, A.N.; Kebreab, E.; Niu, M.; Oh, J.; Bannink, A.; Bayat, A.R.; Boland, T.M.; Brito, A.F.; Casper, D.P.; Crompton, L.A.; et al. Uncertainties in enteric methane inventories, measurement techniques, and prediction models. J. Dairy Sci. 2018, 101, 6655-6674. [CrossRef] [PubMed]

41. Ministry for the Environment. New Zealand's Greenhouse Gas Inventory 1990-2013; New Zealand Governent: Wellington, New Zealand, 2015; ISBN 1179-223X.

42. Dijkstra, J.; Oenema, O.; van Groenigen, J.W.; Spek, J.W.; van Vuuren, A.M.; Bannink, A. Diet effects on urine composition of cattle and $\mathrm{N}_{2} \mathrm{O}$ emissions. Animal 2013, 7, 292-302. [CrossRef] [PubMed]

Publisher's Note: MDPI stays neutral with regard to jurisdictional claims in published maps and institutional affiliations.

(C) 2020 by the authors. Licensee MDPI, Basel, Switzerland. This article is an open access article distributed under the terms and conditions of the Creative Commons Attribution (CC BY) license (http://creativecommons.org/licenses/by/4.0/). 